\title{
Pharmacokinetics, Pharmacodynamics, and Tolerability of Opicapone in Healthy Chinese and Caucasian Subjects: An Open-Label, Single-Center, Phase 1 Study
}

\author{
Duanduan Cong $\cdot$ Jie Song $\cdot$ Yue Liu $\cdot$ Yan Tan $\cdot$ Wei Xue $\cdot$ \\ Xiaohui Liu · Wenyuan Qi · Jun Lu • Xiaojuan Yuan • \\ Yongchun Zhou · Ai-Min Hui · Kexin Li
}

Received: November 15, 2021 / Accepted: December 8, 2021 / Published online: January 10, 2022

(C) The Author(s) 2021

\section{ABSTRACT}

Introduction: This study evaluated the pharmacokinetics (PK) and pharmacodynamics (PD) of single and multiple doses of opicapone (OPC) in healthy Chinese and Caucasian subjects.

Methods: In this open-label, single-center, phase 1 study, eligible Chinese subjects received one of three OPC doses $(25,50$, or $100 \mathrm{mg})$, and Caucasian subjects received either 25 or $50 \mathrm{mg}$

Duanduan Cong and Jie Song contributed equally to this work.

Supplementary Information The online version contains supplementary material available at https:// doi.org/10.1007/s40120-021-00314-8.

D. Cong $\cdot$ Y. Liu $\cdot$ W. Xue $\cdot$ X. Liu $\cdot$ W. Qi $\cdot$ K. Li $(\bowtie)$

Clinical Trial Center, Beijing Hospital, National Center of Gerontology, Institute of Geriatric Medicine, Chinese Academy of Medical Sciences, Assessment of Clinical Drugs Risk and Individual Application Key Laboratory, No. 1 Dahua Road, Dongdan Dongcheng District, Beijing 100005, China

e-mail: kexinli6202@163.com

J. Song $\cdot$ Y. Tan $\cdot$ J. Lu · A.-M. Hui ( $ه)$

Clinical Research Department, Shanghai Fosun

Pharmaceutical Development, Co., Ltd., Shanghai 200000, China

e-mail: aimin.hui@fosunpharma.com

X. Yuan $\cdot$ Y. Zhou

Wanbang Biopharmaceuticals Co., Ltd., Xuzhou, China of OPC. All subjects were administered a single dose of OPC, whereas subjects in the 50-mg OPC group continued to receive once-daily doses of $50 \mathrm{mg}$ OPC for 10 days. The primary endpoint was to evaluate and compare the plasma concentrations and PK parameters of OPC and its main metabolite, and erythrocytesoluble catechol-O-methyltransferase (S-COMT) activity in Chinese subjects with that of Caucasian subjects. The secondary endpoint was to evaluate the safety of OPC in Chinese subjects. The estimated results for geometric mean ratios (GMRs) were evaluated with the standard bioequivalence (BE) limits between $80 \%$ and $125 \%$ to evaluate the ethnic differences. All statistical analyses were performed using SAS version 9.4. Results: In total, 70 subjects (45 Chinese, 25 Caucasian) were enrolled; the majority of them were male $(85.7 \%)$. The plasma exposure of both OPC and BIA 9-1103 increased in an approximately dose-proportional manner in both populations. Maximum S-COMT inhibition ranged from $79 \%$ to $95 \%$ after a single dose and was about $94 \%$ after a 10-day once-daily regimen in both populations. The point estimates of GMRs (Chinese/Caucasian) and 90\% CI, except $C_{\max }$ in 25-mg and 50-mg OPC groups, for PK and PD parameters were within $80 \%$ to $125 \%$. Furthermore, no new risks or safety concerns associated with OPC were identified, indicating a tolerable safety profile in healthy Chinese subjects. 
Conclusion: Ethnicity had no significant impact on $\mathrm{PK}$ and $\mathrm{PD}$ parameters after single or multiple doses of OPC, and OPC was safe and tolerable in healthy Chinese subjects.

Trial Registration: ChiCTR number, CTR20192230.

Keywords: Clinical trial; COMT inhibitor; Ethnicity; Opicapone; Pharmacodynamics; Pharmacokinetics; Tolerability

\section{Key Summary Points}

Why carry out this study?

The available catechol-Omethyltransferase (COMT) inhibitors have clinical limitations. Opicapone (OPC), a novel third-generation COMT inhibitor, was developed to overcome such limitations

We conducted this study to evaluate the pharmacokinetics (PK) and pharmacodynamics (PD) of OPC when administered as single and multiple doses in healthy Chinese and Caucasian subjects

\section{What was learned from the study?}

The plasma exposure of both OPC and BIA 9-1103 increased in an approximately dose-proportional manner in both populations

The point estimates of geometric mean ratios (Chinese/Caucasian) and 90\% CI, except $C_{\max }$ in 25-mg and 50-mg OPC groups, for PK and PD parameters were all within $80 \%$ to $125 \%$, indicating no significant differences in PK and PD profiles between Chinese and Caucasian subjects. Furthermore, no new risks or safety concerns associated with OPC were identified

\section{INTRODUCTION}

For decades, levodopa (L-DOPA) has remained the gold standard in treating Parkinson's disease, a progressive neurodegenerative disease characterized by a deficiency of neurotransmitters, especially dopamine [1-3]. L-DOPA is often used in combination with dopa-decarboxylate inhibitors (DDCIs) to increase its uptake in the brain and reduce side effects [4]. However, only a small proportion of L-DOPA reaches the brain because of the degradation of the drug by the enzyme catechol-O-methyltransferase (COMT) [5]. Therefore, adjunctive therapy with peripheral COMT inhibitors is suggested to inhibit the peripheral levodopa metabolism (O-methylation of L-DOPA to 3-O-methyldopa [3-OMD]) $[6,7]$. Multiple guidelines also recommend COMT inhibitors in patients with advanced Parkinson's disease and motor fluctuations [8-10]. Although the currently available COMT inhibitors, such as tolcapone and entacapone, can enhance the bioavailability of L-DOPA to a certain degree and improve motor function, certain safety and efficacy issues, including the hepatotoxicity of tolcapone [11] and the need for frequent dosing of entacapone $[12,13]$, have limited their use in clinical practice. Therefore, there is an unmet need for COMT inhibitors with a better therapeutic profile without increased safety risk.

To overcome the limitations with present COMT inhibitors, opicapone (OPC), a novel third-generation COMT inhibitor, was developed. It is a hydrophilic 1,2,4-oxadiazole derivative with a pyridine $\mathrm{N}$-oxide residue at position 3 [14]. OPC is absorbed rapidly, predominantly distributed in the liver and kidney [15], and has an exceptionally high affinity (99.9\%) for human plasma proteins [16]. OPC can be metabolized through different pathways, such as sulfation, methylation (by COMT), reduction, glucuronidation, and glutathione conjugation. Among them, sulfation is the primary metabolic pathway and BIA 9-1103 (OPC sulfate) is the major metabolite (inactive) of OPC $[17,18]$. OPC could inhibit one of the two isoforms of COMT, namely the erythrocyte soluble COMT [S-COMT] [19], which is mainly 
expressed in peripheral tissues such as liver, kidney, and erythrocytes. Therefore, the efficacy of OPC can be evaluated by erythrocyte S-COMT inhibition. Rocha et al. reported a maximum erythrocyte S-COMT inhibition $\left(E_{\max }\right)$ in healthy male subjects ranging from $69.9 \%$ to $98.0 \%$ after repeated daily doses of $30 \mathrm{mg}$ OPC [17].

OPC was first approved by the European Union (2016), followed by South Korea (2019), the USA, and Japan (2020). Falcão et al. found no obvious impact of ethnic factors on pharmacokinetics (PK) and pharmacodynamics (PD) profiles of OPC [20]. Besides, in a phase 1 study conducted by Xue et al., healthy Chinese and Caucasian subjects showed comparable PK characteristics of OPC after taking $50 \mathrm{mg}$ OPC in multiple doses [21]. However, very little is known about the exposure-response and safety of OPC when given to the Chinese population. Hence, this study aimed to evaluate the PK and PD profiles of a single dose and multiple doses of OPC in healthy Chinese subjects and compare these parameters with those of matched Caucasian subjects, along with the assessment of safety and tolerability of OPC in healthy Chinese subjects. On the basis of the guidelines of International Council for Harmonisation of Technical Requirements for Pharmaceuticals for Human Use (ICH)-E5 [22], we intended to perform the PK and PD comparisons between the two populations to help in making decisions about extrapolation of foreign clinical data in the Chinese population.

\section{METHODS}

\section{Study Design}

We conducted this open-label, single-center, phase 1 , single ascending and once-daily repeated dose study (ChiCTR number CTR20192230) in healthy Chinese and Caucasian subjects at Beijing Hospital Clinical Trial Center (Beijing, China), in compliance with the Declaration of Helsinki, Good Clinical Practice (GCP) and applicable regulatory requirements. The study protocol was approved by the ethics committee of Beijing Hospital (Beijing, China,
Approval number 2019BJYYEC-100-01). Written informed consent was obtained from each subject before participating in the study.

\section{Study Population}

Male and female healthy subjects (either Caucasian or Chinese) aged 18 to 45 years, with a body mass index (BMI) of 18.5 to $28 \mathrm{~kg} / \mathrm{m}^{2}$ and without clinically significant abnormalities in laboratory tests, electrocardiograms, and vital signs at screening, were included in the study. Subjects who met any of the following criteria were excluded: clinically significant illnesses or disorders; abnormalities in laboratory tests or physical examinations; being pregnant/lactating; a history of smoking/alcoholism; had an allergic or adverse reaction to related drugs (like tolcapone or entacapone); blood donation over $360 \mathrm{~mL}$ within 3 months before enrollment, taking any over-the-counter drugs/Chinese herbal medicines/vitamins within 7 days before enrollment; and any medical history or condition that may affect the safety or the in vivo process of the drug.

The sample size was estimated to meet the requirements of sample size in the Center for Drug Evaluation's 2005 technical guidelines for clinical pharmacokinetics research of chemical drugs [23].

\section{Treatment}

Eligible subjects were assigned to one of the three dosing groups $(25,50$, and $100 \mathrm{mg}$ OPC). The dose range was based on the previous phase 3 trials which showed that a 50-mg oncedaily regimen had better efficacy and comparable safety in patients with Parkinson's disease than lower-dose regimens (i.e., 5 and $25 \mathrm{mg}$ ) $[24,25]$. In addition, the US Food and Drug Administration has approved the 50-mg oncedaily dose of OPC to be taken at bedtime in patients with Parkinson's disease [26]. The 25and 50-mg groups recruited both Chinese and Caucasians, while the 100-mg group recruited only Chinese subjects. This was because of the difficulty of enrolling the Caucasians, and studying only $25-\mathrm{mg}$ and $50-\mathrm{mg}$ doses in 


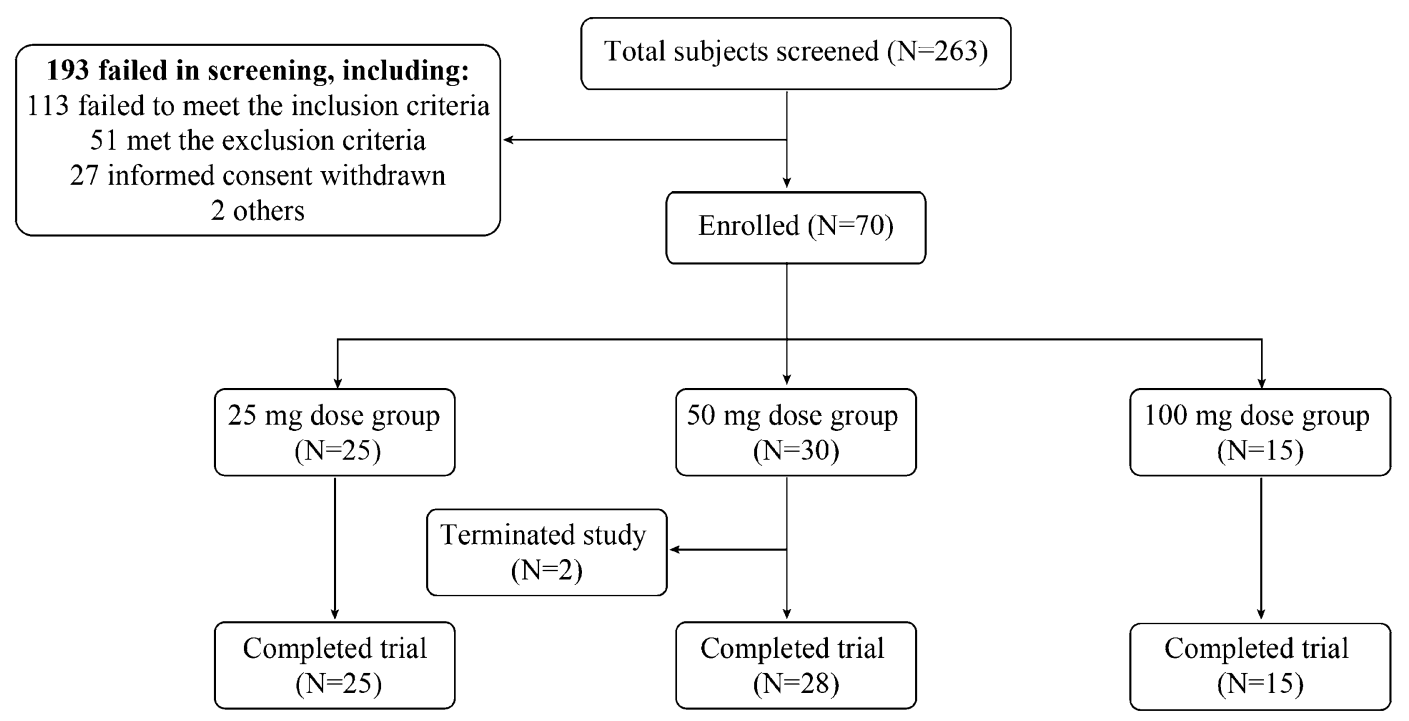

Fig. 1 Flowchart of sample disposition

Caucasians was considered adequate to detect sensitivity to ethnicity. The purpose of giving $100 \mathrm{mg}$ to the Chinese population was to understand PK and PD parameters of OPC when given at a higher dose than recommended. Each subject received a single dose of OPC as per group allocation $(25,50$, or $100 \mathrm{mg})$. To reveal both the single-dose and steady-state PK and PD characteristics of OPC, subjects in the 50-mg group received a single dose of OPC and an additional $50 \mathrm{mg}$ OPC once daily for 10 consecutive days.

In the single-dose phase, all subjects received OPC on the morning of day 1 and were monitored at the clinical site for approximately $24 \mathrm{~h}$ post-dose and then discharged. On the morning of day 3 and day 4, they returned to the site for blood sample collection and safety assessments. In the multiple-dose phase, subjects in the 50-mg group continued to receive OPC once daily from day 5 to day 14 . On day 12 , they were readmitted to the clinical site and were discharged on day 20 after completing a 144-h assessment post last dose (day 14).

\section{Sample Collection}

Blood samples for PK analysis were collected within $1 \mathrm{~h}$ before the dose on day 1 and at 0.25 , $0.5,0.75,1,1.5,2,3,4,5,6,8,10,12,24,48$, and $72 \mathrm{~h}$ post-dose in the single-dose phase; and within $1 \mathrm{~h}$ pre-dose on days $5,12,13$, and 14 and at $0.25,0.5,0.75,1,1.5,2,3,4,5,6,8,10$, $12,24,48,72,96,120$, and $144 \mathrm{~h}$ after the last dose in the multiple-dose phase. Blood samples for PD analysis were collected pre-dose on day 1 and at $0.5,1,2,4,6,10$, and $24 \mathrm{~h}$ post-dose in the single-dose phase; and pre-dose on day 14 and at $0.5,1,2,4,6,10,24,48,72,96,120$, and $144 \mathrm{~h}$ after the last dose in the multiple-dose phase.

\section{Bioanalytical Methods for PK and PD Analysis}

Blood samples (6 $\mathrm{mL}$ at each point) were collected in ice-cold tubes containing potassium ethylenediaminetetraacetic acid ( $\mathrm{K}_{2}$ EDTA), followed by centrifugation at $1500 \times g$ at $4{ }^{\circ} \mathrm{C}$ for approximately $10 \mathrm{~min}$. The resulting plasma was transferred into a collection tube. The remaining erythrocytes were washed three times under the same centrifugal conditions 
Table 1 Summary of demographic data

\begin{tabular}{|c|c|c|c|c|c|c|c|}
\hline \multicolumn{2}{|c|}{ Demographics } & \multicolumn{2}{|c|}{$25 \mathrm{mg}(N=25)$} & \multicolumn{2}{|c|}{$50 \mathrm{mg}(N=30)$} & \multirow{2}{*}{$\begin{array}{l}100 \mathrm{mg} \\
\text { Chinese } \\
\text { subjects } \\
(N=15)\end{array}$} & \multirow[t]{2}{*}{ Total } \\
\hline & & $\begin{array}{l}\text { Chinese } \\
\text { subjects } \\
(N=15)\end{array}$ & $\begin{array}{l}\text { Caucasian } \\
\text { subjects } \\
(N=10)\end{array}$ & $\begin{array}{l}\text { Chinese } \\
\text { subjects } \\
(N=15)\end{array}$ & $\begin{array}{l}\text { Caucasian } \\
\text { subjects } \\
(N=15)\end{array}$ & & \\
\hline \multirow{2}{*}{$\begin{array}{l}\text { Sex, } \\
\qquad n(\%)\end{array}$} & Male & $14(93.3)$ & $9(90.0)$ & $12(80.0)$ & $11(73.3)$ & $14(93.3)$ & $60(85.7)$ \\
\hline & Female & $1(6.7)$ & $1(10.0)$ & $3(20.0)$ & $4(26.7)$ & $1(6.7)$ & $10(14.3)$ \\
\hline \multirow{3}{*}{$\begin{array}{l}\text { Age } \\
\text { (years) }\end{array}$} & Mean \pm SD & $28.8 \pm 6.5$ & $27.5 \pm 5.9$ & $31.3 \pm 6.6$ & $25.1 \pm 3.7$ & $27.5 \pm 5.3$ & $28.1 \pm 5.9$ \\
\hline & Min, $\max$ & 21,44 & 20,41 & 22,40 & 19,35 & 19,38 & 19,44 \\
\hline & $\begin{array}{l}\text { Median } \\
\qquad(\mathrm{Q} 1, \mathrm{Q} 3)\end{array}$ & $\begin{array}{c}27.0(25.0 \\
32.0)\end{array}$ & $\begin{array}{c}27.5(24.0 \\
30.0)\end{array}$ & $\begin{array}{c}32.0(26.0 \\
39.0)\end{array}$ & $\begin{array}{c}25.0(23.0 \\
27.0)\end{array}$ & $\begin{array}{c}28.0(23.0 \\
31.0)\end{array}$ & $\begin{array}{c}27.0(24.0 \\
31.0)\end{array}$ \\
\hline \multirow{3}{*}{$\begin{array}{l}\text { Body } \\
\text { weight } \\
(\mathrm{kg})\end{array}$} & Mean $\pm S D$ & $64.5 \pm 8.1$ & $69.0 \pm 9.3$ & $68.3 \pm 8.4$ & $71.6 \pm 10.7$ & $64.5 \pm 10.4$ & $67.5 \pm 9.6$ \\
\hline & Min, $\max$ & $50.3,76.5$ & $54.5,80.1$ & $54.9,81.5$ & $49.8,93.0$ & $52.0,88.4$ & $49.8,93.0$ \\
\hline & $\begin{array}{l}\text { Median } \\
\quad(\mathrm{Q} 1, \mathrm{Q} 3)\end{array}$ & $\begin{array}{c}64.8(58.6 \\
72.2)\end{array}$ & $\begin{array}{c}71.8(59.9 \\
76.2)\end{array}$ & $\begin{array}{c}67.8(59.7 \\
75.4)\end{array}$ & $\begin{array}{c}72.6(66.1 \\
78.2)\end{array}$ & $\begin{array}{c}62.7(56.7 \\
68.0)\end{array}$ & $\begin{array}{c}67.9(59.3 \\
74.9)\end{array}$ \\
\hline \multirow{3}{*}{$\begin{array}{l}\text { Height } \\
(\mathrm{cm})\end{array}$} & Mean $\pm S D$ & $165.7 \pm 5.4$ & $172.8 \pm 5.1$ & $170.0 \pm 8.4$ & $173.6 \pm 9.7$ & $169.9 \pm 7.3$ & $170.2 \pm 7.9$ \\
\hline & Min, $\max$ & $154.9,175.5$ & $164.8,181.7$ & $153.6,180.6$ & $148.8,185.1$ & $159.1,185.2$ & $148.8,185.2$ \\
\hline & $\begin{array}{l}\text { Median } \\
\quad(\mathrm{Q} 1, \mathrm{Q} 3)\end{array}$ & $\begin{array}{c}165.2(162.5 \\
170.0)\end{array}$ & $\begin{array}{c}173.3(169.7 \\
176.5)\end{array}$ & $\begin{array}{c}170.4(163.1, \\
177.8)\end{array}$ & $\begin{array}{c}177.4(168.4 \\
178.8)\end{array}$ & $\begin{array}{c}168.8(163.8 \\
173.3)\end{array}$ & $\begin{array}{c}170.2 \\
(164.8 \\
176.5)\end{array}$ \\
\hline \multirow{3}{*}{$\begin{array}{c}\text { BMI }(\mathrm{kg} / \\
\left.\mathrm{m}^{2}\right)\end{array}$} & Mean $\pm S D$ & $23.5 \pm 2.7$ & $23.1 \pm 2.6$ & $23.6 \pm 2.0$ & $23.6 \pm 1.8$ & $22.2 \pm 2.1$ & $23.2 \pm 2.2$ \\
\hline & Min, $\max$ & $19.4,27.4$ & $19.7,26.5$ & $20.1,26.5$ & $20.8,27.6$ & $19.6,26.3$ & $19.4,27.6$ \\
\hline & $\begin{array}{l}\text { Median } \\
\quad(\mathrm{Q} 1, \mathrm{Q} 3)\end{array}$ & $\begin{array}{c}24.3(21.1 \\
25.9)\end{array}$ & $\begin{array}{c}22.7(20.5 \\
25.5)\end{array}$ & $\begin{array}{c}23.3(21.8 \\
25.5)\end{array}$ & $\begin{array}{c}23.7(22.5 \\
24.5)\end{array}$ & $\begin{array}{c}22.2(20.5 \\
23.8)\end{array}$ & $\begin{array}{c}23.0(21.3 \\
25.0)\end{array}$ \\
\hline
\end{tabular}

$B M I$ body mass index, $S D$ standard deviation, $Q 1$ first quartile, $Q 3$ third quartile

with twice the volume of ice-cold sodium chloride solution $(0.9 \%)$. Both the plasma and washed erythrocytes were stored immediately at $-70{ }^{\circ} \mathrm{C}$ until shipment to a central lab.

Although BIA 9-1103 has no activity and safety risks, in a human mass balance study (unpublished data), it was observed that the exposure of BIA 9-1103 accounted for more than $50 \%$ of the total exposure; hence, the exposure of primary metabolite BIA 9-1103 was also evaluated. At the central lab, plasma concentrations of OPC and its major metabolite BIA 9-1103 were determined using liquid chromatography-tandem mass spectrometry (LC-MS/MS). S-COMT assay was carried out using the washed erythrocytes in compliance with Good Laboratory Practice (GLP) at BIAL's Pharmacological Laboratory (S. Mamede do Coronado, Portugal) according to a validated method [27, 28]. The S-COMT activity was expressed as the amount of metanephrine (in picomoles) formed by the action of erythrocyte S-COMT upon epinephrine, per milligram of hemoglobin in the sample per hour [pmol/ $(\mathrm{mgHb} / \mathrm{h})]$. 

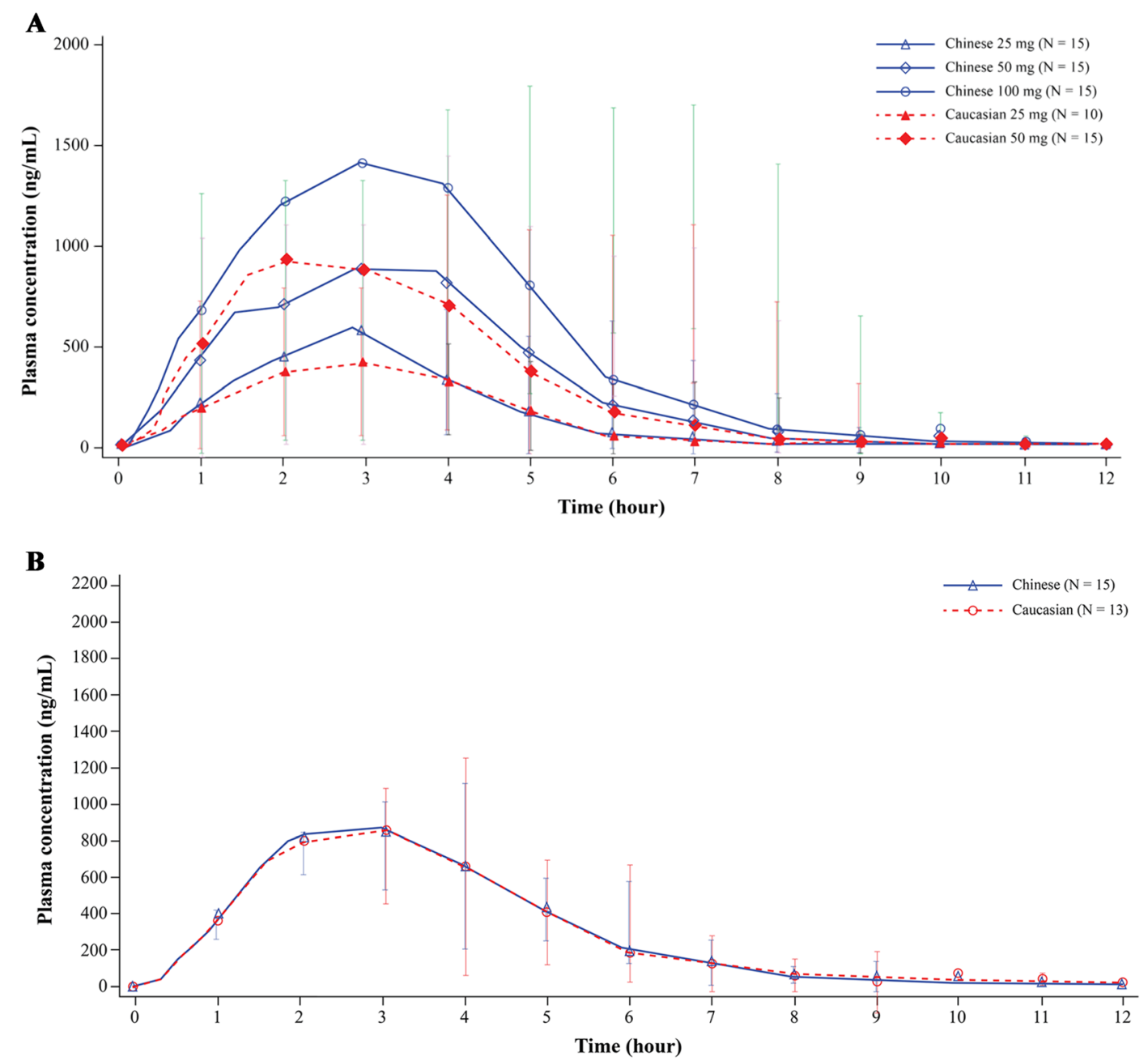

Fig. 2 Mean plasma concentration-time profiles: a opicapone single dose; b opicapone multiple dose; c BIA 9-1103 single dose; d BIA 9-1103 multiple dose. Error bars represent standard deviation

\section{Pharmacokinetic Analysis}

Parameters were calculated by non-compartmental analysis using WinNonlin ${ }^{\circledR}$ (Version 8.3, Pharsight Corporation, Mountain View, California, USA). The following PK parameters of OPC and BIA 9-1103, such as maximum observed plasma concentration $\left(C_{\max }\right.$, including $C_{\max }$ in the steady state $\left.\left[C_{\max , s s}\right]\right)$, time to reach $C_{\max }\left(T_{\max }\right)$, area under the plasma concentration-time curve (AUC, including $\mathrm{AUC}_{0-t}$ following a single dose and $\mathrm{AUC}_{0-\tau}$ following multiple doses), the elimination half-life $\left(t_{1 / 2}\right)$, the apparent clearance $(\mathrm{CL} / F)$, and the apparent volume of distribution $\left(V_{\mathrm{d}} / F\right)$, were calculated from the individual plasma concentration versus time profiles.

\section{Pharmacodynamics Analysis}

The PD parameters derived from the individual S-COMT activity profiles using WinNonlin ${ }^{\circledR}$ included the S-COMT activity at maximum effect $\left(E_{\max }\right)$, time to reach $E_{\max }\left(\mathrm{TE}_{\max }\right)$, and area under the inhibition of S-COMT activity-time curve $\left(\mathrm{AUEC}_{0-t}\right.$, including $\mathrm{AUEC}_{0-24 \mathrm{~h}}$ following a single dose and $\mathrm{AUEC}_{0-144 \mathrm{~h}}$ following multiple doses). The maximum inhibition 

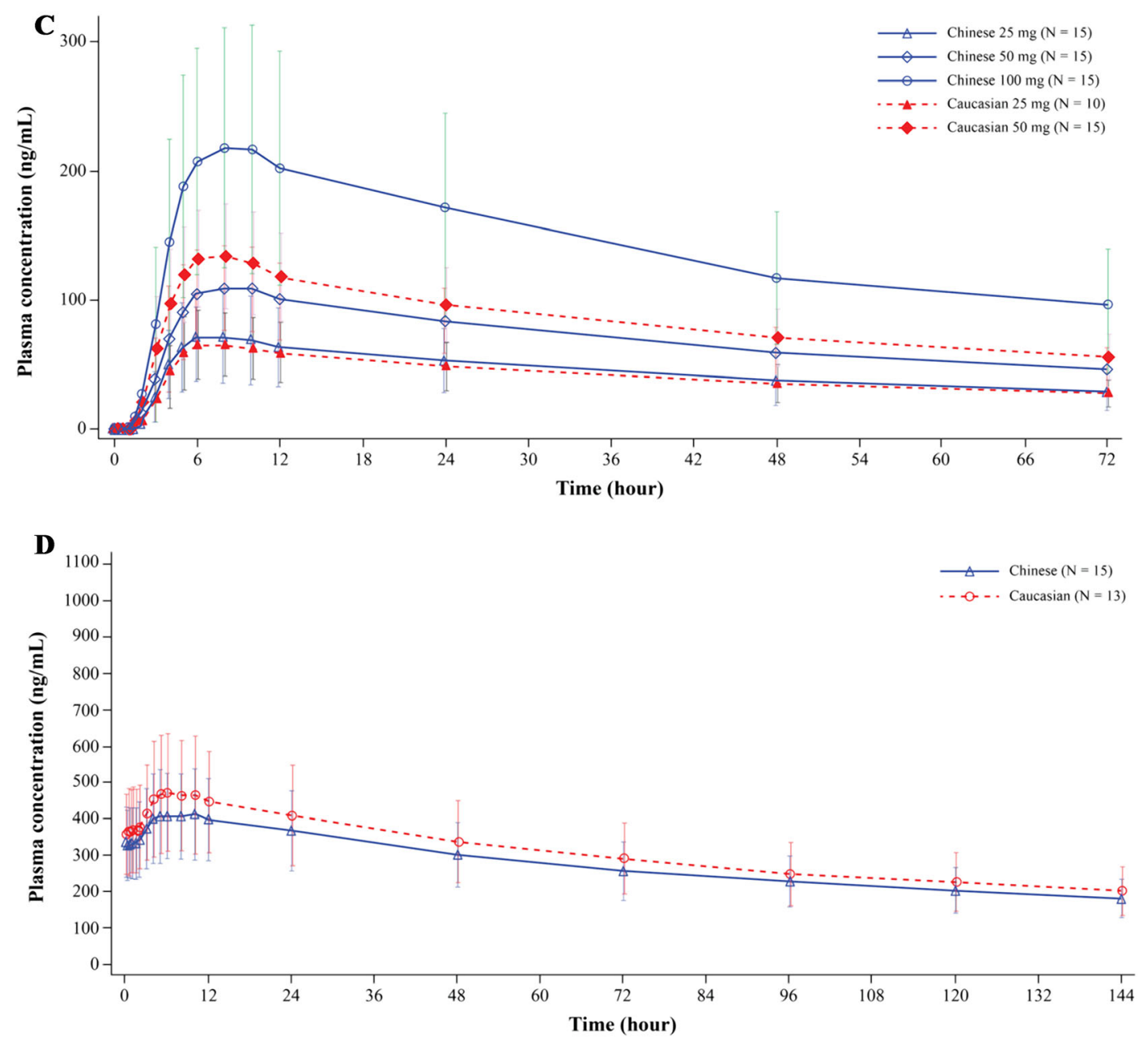

Fig. 2 continued

of S-COMT was calculated as ([E $\left.E_{0}-E_{\max }\right] /$ $\left.E_{0}\right) \times 100 \%$, where $E_{0}$ is the S-COMT activity at baseline before the first dose of OPC on day 1 .

\section{Safety Assessments}

The safety and tolerability of OPC were evaluated throughout the study by assessing treatment-emergent adverse events (AEs), vital signs, laboratory results, physical examination findings, and a 12-lead electrocardiogram (ECG). AEs were coded according to the Medical Dictionary for Regulatory Activities (MedDRA; version 23.0).

\section{Statistical Analysis}

SAS version 9.4 (SAS Institute Inc, Cary, NC, USA) was used primarily to analyze PK and PD data of OPC in Chinese and Caucasian subjects after single-dose and multiple-dose administration. Demographics, PK, and PD parameters were summarized descriptively as per dosing groups. PK and PD parameters for each group are presented as mean (coefficient of variation [CV] \%) or median (minimum, maximum), and were compared between Chinese and Caucasian subjects. The nonlinear mixed-effects modeling (NONMEM, version 7.4, ICON Development Solutions, USA) was used to set up a population PK model. One- and two-compartment models 

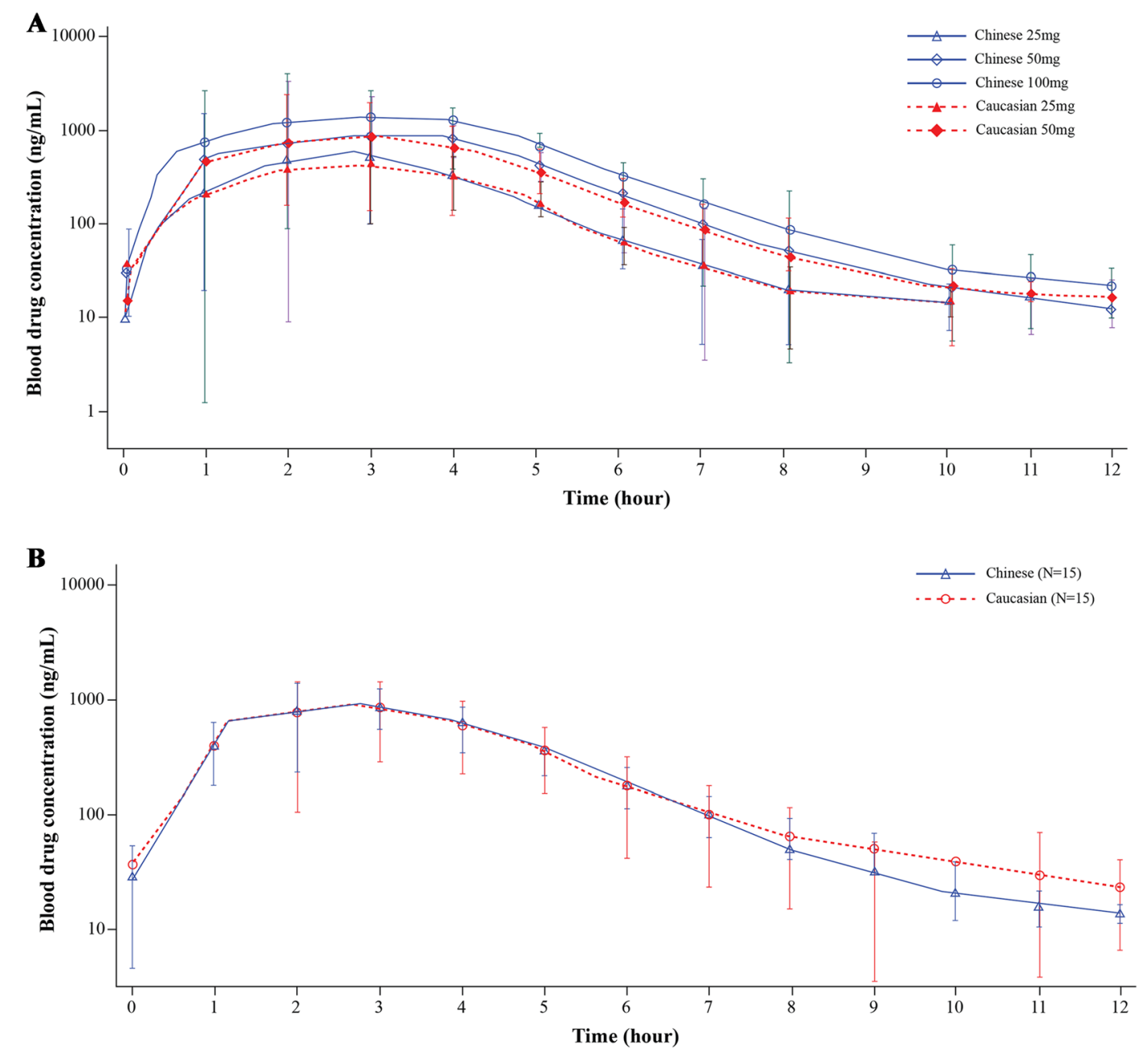

Fig. 3 Semi-logarithmic mean plasma concentration-time profiles: a opicapone single dose; b opicapone multiple doses; c BIA 9-1103 single dose; d BIA 9-1103 multiple dose. Error bars represent standard deviation

with two-phase absorption respectively best described the PK and PD of OPC and the PK of BIA 9-1103 in healthy Chinese and Caucasian subjects. Furthermore, race, gender, age, body weight, BMI, alanine aminotransferase, albumin, and creatinine were estimated in covariate analysis. The PK and PD model was evaluated using the goodness of fit plots and bootstrap method. Visual inspection was performed to assess the predictive ability of the final model. Moreover, the simulated PK and PD parameters along with the geometric mean ratios (GMRs; Chinese/Caucasian) and their 90\% confidence intervals (CIs) were evaluated.

\section{RESULTS}

\section{Demographic Characteristics of Subjects}

In total, 70 eligible subjects (45 Chinese, 25 Caucasian) with a mean (SD) age of 28.1 (5.9) years and a mean BMI of $23.2(2.2) \mathrm{kg} / \mathrm{m}^{2}$ were enrolled in this study. The coronavirus disease (COVID-19) pandemic posed recruiting challenges; consequently, 10 Caucasian subjects, instead of 15 , were recruited to the $25-\mathrm{mg}$ group. The subjects' disposition is presented in Fig. 1 and detailed demographic characteristics of the eligible subjects and their group 

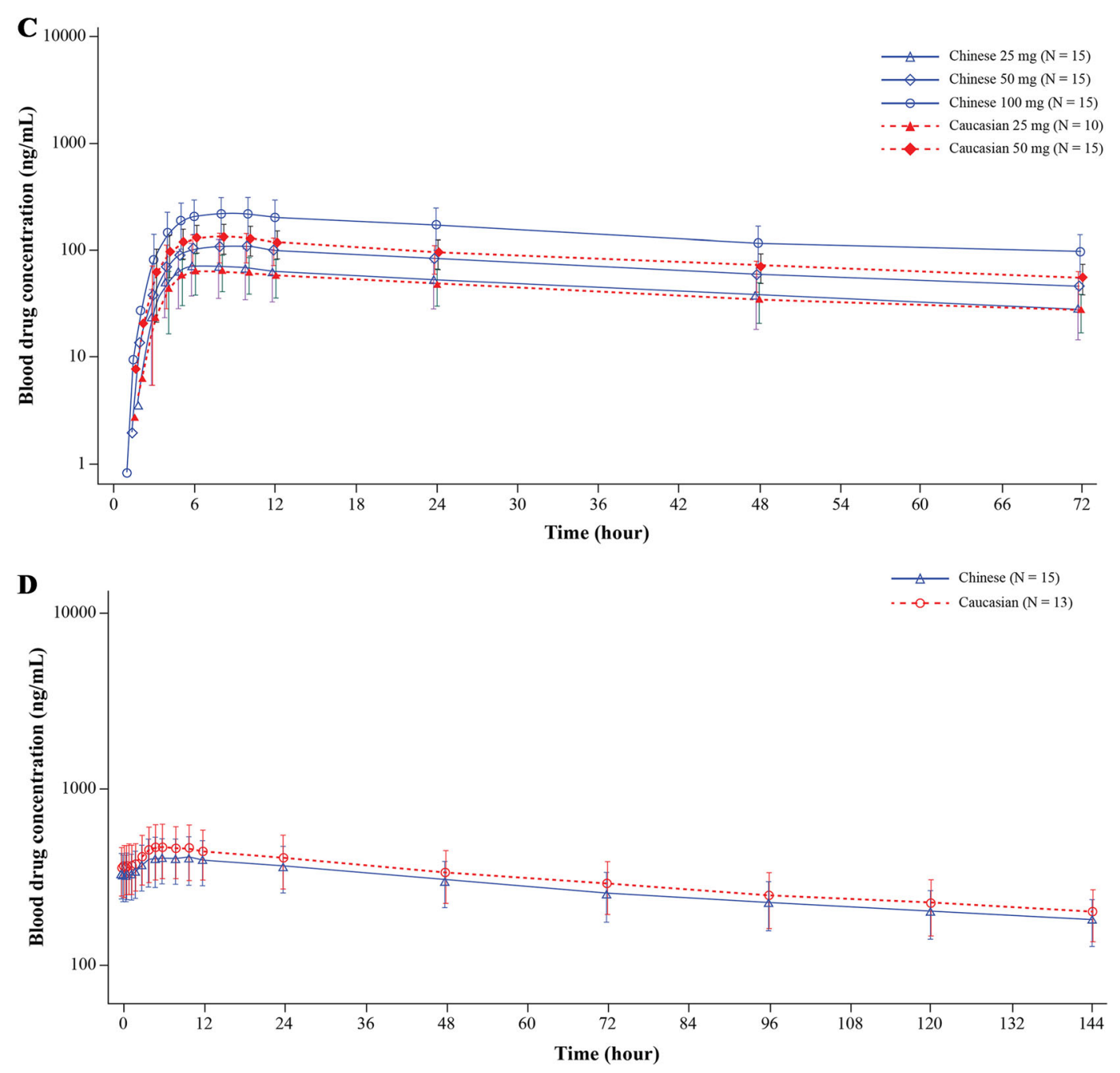

Fig. 3 continued

assignment are presented in Table 1. Overall, 68 subjects completed the study (two subjects discontinued because of adverse events). All subjects were included in the full analysis set and the PK, PD, and safety analysis sets.

\section{Pharmacokinetics}

The mean plasma concentration-time profiles and semi-logarithmic plasma concentration-time profiles of OPC and its major metabolite BIA 9-1103 are presented in Figs. 2 and 3, respectively. The trends of concentration-time curves were similar among different groups and ethnicities, irrespective of the single- or multiple-dose administration. The key PK parameters of OPC and BIA 9-1103 after a single dose or multiple doses in Chinese and Caucasian subjects are summarized in Table 2. The $C_{\max }$ and $\mathrm{AUC}_{0-t}$ of both OPC and BIA 91103 showed a dose-dependent increase in both Chinese and Caucasians after single and multiple doses. For Chinese subjects, the mean $C_{\max }$ values of OPC after a single dose of 25 and $50 \mathrm{mg}$ were 713.6 and $1210.5 \mathrm{ng} / \mathrm{mL}$, respectively, whereas the mean $\mathrm{AUC}_{0-t}$ values were 1848.9 and $3875.2 \mathrm{~h} \mathrm{ng} / \mathrm{mL}$, respectively. A similar trend was observed in Caucasian 
Table 2 Pharmacokinetics parameters of opicapone and BIA 9-1103 after single- and multiple-dose administrations

\begin{tabular}{|c|c|c|c|c|c|c|c|c|c|}
\hline Analytes & $N$ & $t_{\max }(\mathbf{h})$ & $\begin{array}{l}C_{\max } \text { or } \\
C_{\max , s s}(\mathrm{ng} / \\
\mathrm{mL})\end{array}$ & $\begin{array}{l}C_{\min } \\
(\mathbf{n g} / \\
\mathrm{mL})\end{array}$ & $\begin{array}{l}\mathrm{AUC}_{\mathbf{0 - t}} \\
(\mathrm{h} \text { ng/ } \\
\mathrm{mL})\end{array}$ & $\begin{array}{l}\operatorname{AUC}_{0-\infty} \text { or } \\
\operatorname{AUC}_{0-\tau}(\mathrm{h} \mathrm{ng} / \\
\mathrm{mL})\end{array}$ & $\begin{array}{l}V_{\mathrm{d}} / \\
F(\mathrm{~L})\end{array}$ & $\begin{array}{l}\text { CL/ } \\
F(\mathbf{L} / \mathbf{h})\end{array}$ & $t_{1 / 2}(\mathrm{~h})$ \\
\hline \multicolumn{10}{|c|}{ OPC (single dose) } \\
\hline $\begin{array}{l}\text { Chinese: } \\
25 \mathrm{mg}\end{array}$ & 15 & $3(1.5-5)$ & $713.6(35.9)$ & - & $\begin{array}{r}1848.9 \\
(41.8)\end{array}$ & $2100.1(32.5)$ & $\begin{array}{l}13.4 \\
\quad(32.4)\end{array}$ & $\begin{array}{l}13.3 \\
(36.8)\end{array}$ & $\begin{array}{l}0.7 \\
\quad(24.3)\end{array}$ \\
\hline $50 \mathrm{mg}$ & 15 & $3(1.5-4)$ & $1210.5(25.8)$ & - & $\begin{array}{r}3875.2 \\
(30.7)\end{array}$ & $3913.8(30.2)$ & $\begin{array}{l}21.8 \\
\quad(57.1)\end{array}$ & $\begin{array}{l}13.8 \\
(28.3)\end{array}$ & $\begin{array}{l}1.1 \\
\quad(52.3)\end{array}$ \\
\hline $100 \mathrm{mg}$ & 15 & $2(1-5)$ & $1898.0(23.4)$ & - & $\begin{array}{r}6205.1 \\
(30.9)\end{array}$ & $6243.7(30.9)$ & $\begin{array}{l}32.1 \\
\quad(29.4)\end{array}$ & $\begin{array}{l}17.9 \\
(37.9)\end{array}$ & $\begin{array}{l}1.3 \\
(26.1)\end{array}$ \\
\hline $\begin{array}{l}\text { Caucasian: } \\
25 \mathrm{mg}\end{array}$ & 10 & $3(0.75-5)$ & $556.3(35.7)$ & - & $\begin{array}{r}1622.8 \\
(24.7)\end{array}$ & $1728.3(19.5)$ & $\begin{array}{l}15.0 \\
(26.2)\end{array}$ & $\begin{array}{l}15.0 \\
(20.3)\end{array}$ & $\begin{array}{l}0.7 \\
\quad(17.0)\end{array}$ \\
\hline $50 \mathrm{mg}$ & 15 & $2(1-4.02)$ & $1327.8(31.8)$ & - & $\begin{array}{c}3802.1 \\
(29.2)\end{array}$ & $3823.9(29.1)$ & $\begin{array}{l}17.4 \\
(22.6)\end{array}$ & $\begin{array}{l}14.2 \\
(30.9)\end{array}$ & $\begin{array}{l}0.9 \\
\quad(30.6)\end{array}$ \\
\hline \multicolumn{10}{|c|}{ BIA 9-1103 (single dose) } \\
\hline $\begin{array}{l}\text { Chinese: } \\
25 \mathrm{mg}\end{array}$ & 15 & $6(5-12)$ & $75.0(48.2)$ & - & $\begin{array}{r}3169.4 \\
(48.9)\end{array}$ & $5402.5(50.8)$ & $\begin{array}{l}446.0 \\
(50.7)\end{array}$ & $\begin{array}{l}6.1 \\
\quad(56.9)\end{array}$ & $\begin{array}{l}52.6 \\
\quad(12.3)\end{array}$ \\
\hline $50 \mathrm{mg}$ & 15 & $8(5-10)$ & $112.3(29.7)$ & - & $\begin{array}{l}4990.2 \\
(32.0)\end{array}$ & $8630.2(38.8)$ & $\begin{array}{l}476.6 \\
(22.3)\end{array}$ & $\begin{array}{l}6.5 \\
(30.4)\end{array}$ & $\begin{array}{l}52.8 \\
(13.4)\end{array}$ \\
\hline $100 \mathrm{mg}$ & 15 & $8(5-10)$ & $224.1(43.1)$ & - & $\begin{array}{c}10,084.4 \\
(43.0)\end{array}$ & $17,712.8(44.2)$ & $\begin{array}{l}542.7 \\
(50.6)\end{array}$ & $\begin{array}{l}6.9 \\
\quad(47.6)\end{array}$ & $\begin{array}{l}54.7 \\
\quad(9.1)\end{array}$ \\
\hline $\begin{array}{l}\text { Caucasian: } \\
25 \mathrm{mg}\end{array}$ & 10 & $7(5-10)$ & $68.3(37.2)$ & - & $\begin{array}{l}2950.9 \\
(40.5)\end{array}$ & $5290.4(40.3)$ & $\begin{array}{l}453.3 \\
(37.4)\end{array}$ & $\begin{array}{l}5.5 \\
(40.4)\end{array}$ & $\begin{array}{l}58.0 \\
\quad(11.9)\end{array}$ \\
\hline $50 \mathrm{mg}$ & 15 & $6(4-8)$ & $139.0(31.1)$ & - & $\begin{array}{l}5935.5 \\
(30.1)\end{array}$ & $10,801.3(31.8)$ & $\begin{array}{l}433.5 \\
(28.7)\end{array}$ & $\begin{array}{l}5.1 \\
\quad(32.8)\end{array}$ & $\begin{array}{l}59.9 \\
\quad(14.1)\end{array}$ \\
\hline \multicolumn{10}{|c|}{ OPC (multiple doses) } \\
\hline $\begin{array}{l}\text { Chinese: } \\
50 \mathrm{mg}\end{array}$ & 15 & $2.4(1-4)$ & $1127.7(24.6)$ & ${ }^{*} 0.0(-)$ & - & $3594.8(20.8)$ & - & - & $\begin{array}{l}1.3 \\
(32.6)\end{array}$ \\
\hline $\begin{array}{l}\text { Caucasian: } \\
50 \mathrm{mg}\end{array}$ & 13 & $\begin{array}{l}3.0 \\
\quad(1.5-5.0)\end{array}$ & $1208.4(39.5)$ & ${ }^{*} 0.0(-)$ & - & $3797.3(29.5)$ & - & - & $\begin{array}{l}1.6 \\
(44.1)\end{array}$ \\
\hline \multicolumn{10}{|c|}{ BIA 9-1103 (multiple doses) } \\
\hline $\begin{array}{l}\text { Chinese: } \\
50 \mathrm{mg}\end{array}$ & 15 & $6(4-12)$ & $423.3(29.9)$ & $\begin{array}{l}319.7 \\
\quad(30.2)\end{array}$ & - & $9252.6(29.1)$ & - & - & $\begin{array}{l}137.2 \\
(29.3)\end{array}$ \\
\hline
\end{tabular}


Table 2 continued

\begin{tabular}{|c|c|c|c|c|c|c|c|c|c|}
\hline Analytes & $N$ & $t_{\max }(\mathrm{h})$ & $\begin{array}{l}C_{\max } \text { or } \\
C_{\max , s s}(\mathrm{ng} / \\
\mathrm{mL})\end{array}$ & $\begin{array}{l}C_{\min } \\
(\mathbf{n g} / \\
\mathrm{mL})\end{array}$ & $\begin{array}{l}\mathrm{AUC}_{0-t} \\
(\mathrm{~h} \text { ng/ } \\
\mathrm{mL})\end{array}$ & $\begin{array}{l}\operatorname{AUC}_{0-\infty} \text { or } \\
\operatorname{AUC}_{0-\tau}(\mathbf{h ~ n g} / \\
\mathrm{mL})\end{array}$ & $\begin{array}{l}V_{\mathrm{d}} / \\
\boldsymbol{F}(\mathbf{L})\end{array}$ & $\begin{array}{l}\text { CL/ } \\
F(\mathbf{L} / \mathbf{h})\end{array}$ & $t_{1 / 2}(\mathrm{~h})$ \\
\hline $\begin{array}{l}\text { Caucasian: } \\
50 \mathrm{mg}\end{array}$ & 13 & $6(4-12)$ & $493.2(32.6)$ & $\begin{array}{l}344.6 \\
(31.2)\end{array}$ & - & $10,414.1(32.4)$ & - & - & $\begin{array}{l}124.5 \\
(14.7)\end{array}$ \\
\hline
\end{tabular}

$A U C_{0-t}$ area under the plasma concentration-time curve from time 0 to the last sampling time with concentrations above the lower limit of quantitation, $A U C_{0-\infty}$ area under the plasma concentration-time curve from time 0 to infinity, $A U C_{0-\tau}$ area under the plasma concentration-time curve over the dosing interval, $C_{\max }$ maximum observed plasma concentration, $C_{\text {max }, s} C_{\max }$ in steady state, $C_{\min }$ minimum plasma concentration, $C L / F$ apparent volume of the central compartment cleared of drug per unit time, $O P C$ opicapone, $t_{1 / 2}$ terminal plasma half-life

Data for $t_{\max }$ are presented as median (min, max); other data are presented as mean (coefficient of variation, \%); ${ }^{*}$ Represents below the limit of quantification (BLQ)

subjects; the mean $C_{\max }$ values of OPC after a single dose of 25 and $50 \mathrm{mg}$ were 556.3 and $1327.8 \mathrm{ng} / \mathrm{mL}$, respectively, and the mean $\mathrm{AUC}_{0-t}$ values were 1622.8 and $3802.1 \mathrm{~h} \mathrm{ng} / \mathrm{mL}$, respectively. The clearance was consistent with all doses (Table 2). The key plasma PK parameters of OPC and BIA 9-1103 were compared between Chinese and Caucasian subjects following single and multiple doses. The point estimates of GMRs (Chinese/Caucasian) for key parameters (i.e., $C_{\max }$ or $C_{\max , \mathrm{ss}}$ and $\mathrm{AUC}_{0-t}$ or $\left.\mathrm{AUC}_{0-\tau}\right)$ all fell between $80 \%$ and $125 \%$ (Table 3).

\section{Pharmacodynamics}

Figure 4 depicts the changes in the S-COMT activity over time after taking single or multiple doses of OPC. The inhibitory effect on S-COMT was observed immediately after taking OPC orally in all groups, which reached the maximum at about $4 \mathrm{~h}$ post-dose and then gradually decreased but did not return to the baseline level. During the multiple-dose phase, the activity of S-COMT was continuously inhibited. No apparent differences were observed in the inhibitory effect of OPC between Chinese and Caucasian subjects in the same dosing group. After administration of a single dose of OPC, the maximum inhibition of S-COMT and AUEC $_{0-24 \mathrm{~h}}$ increased as the dose rose from 25 to $100 \mathrm{mg}$ in Chinese subjects (the maximum
S-COMT inhibition 82.7-95.2\%, AUEC $_{0-24 h}$ $1475.9-1825.8 \% \mathrm{~h}$ ) and from 25 to $50 \mathrm{mg}$ in Caucasian subjects (the maximum S-COMT inhibition 79.7-91.2\%, $\quad$ AUEC $_{0-24 \mathrm{~h}}$ 1472.7-1738.3\% h; Table 4).

The maximum percentage inhibition values of S-COMT after single vs multiple administrations of OPC in 50-mg dose groups in Chinese and Caucasian subjects were $90.3 \%$ vs $94.3 \%$ and $91.2 \%$ vs $94.4 \%$, respectively. Similarly, AUEC $_{0-24 \mathrm{~h}}$ values in single-dose administration vs AUEC $_{0-144 \mathrm{~h}}$ in multiple dose administrations of OPC 50-mg dose groups were 1742.5 vs $8612.0 \% \mathrm{~h}$ and 1738.3 vs $7919.1 \% \mathrm{~h}$ in Chinese and Caucasians, respectively. After administration of multiple doses of $50 \mathrm{mg}$ OPC, the maximum inhibition of S-COMT, $E_{\max }$, and AUEC $_{0-144 \mathrm{~h}}$ were similar in both Chinese and Caucasian subjects. The $90 \%$ CIs of GMRs for $E_{\text {max }}$ and $\mathrm{AUEC}_{0-t}\left(\mathrm{AUEC}_{0-24 \mathrm{~h}}\right.$ or $\left.\mathrm{AUEC}_{0-144 \mathrm{~h}}\right)$ in both phases all fell between $80 \%$ and $125 \%$ (Table 5), which matches the earlier PK results.

\section{Safety and Tolerability}

In total, 17 subjects (24.3\%) experienced $23 \mathrm{AEs}$ during the study, most of which were mild in severity and were self-limited. Only two AEs experienced by two Caucasian subjects were moderate in intensity [presyncope (50 mg group, considered possibly related to the administration of OPC) and the elevated 
Table 3 Comparison of pharmacokinetic parameters of opicapone and BIA 9-1103 after single- and multiple-dose administrations

\begin{tabular}{|c|c|c|c|c|}
\hline Parameter & $N$ & GM (LSM) & GMR (Chinese/Caucasian; \%) & $90 \%$ CI of GMR \\
\hline \multicolumn{5}{|l|}{$\overline{\mathrm{OPC}}$} \\
\hline \multicolumn{5}{|c|}{ Single dose $(25 \mathrm{mg})$} \\
\hline \multicolumn{5}{|c|}{$C_{\max }(\mathrm{ng} / \mathrm{mL})$} \\
\hline Chinese & 15 & 444.1 & 109.2 & $86.5-137.7$ \\
\hline Caucasian & 10 & 406.8 & & \\
\hline \multicolumn{5}{|c|}{$\mathrm{AUC}_{0-t}(\mathrm{~h} \mathrm{ng} / \mathrm{mL})$} \\
\hline Chinese & 15 & 1552.4 & 105.1 & $88.4-124.9$ \\
\hline Caucasian & 10 & 1477.7 & & \\
\hline \multicolumn{5}{|c|}{$\mathrm{AUC}_{0-\infty}(\mathrm{h} \mathrm{ng} / \mathrm{mL})$} \\
\hline Chinese & 15 & 1555.0 & 105.1 & $88.4-124.9$ \\
\hline Caucasian & 10 & 1480.2 & & \\
\hline \multicolumn{5}{|c|}{ Single dose $(50 \mathrm{mg})$} \\
\hline \multicolumn{5}{|c|}{$C_{\max }(\mathrm{ng} / \mathrm{mL})$} \\
\hline Chinese & 15 & 917.2 & 93.4 & $77.0-113.3$ \\
\hline Caucasian & 15 & 981.9 & & \\
\hline \multicolumn{5}{|c|}{$\mathrm{AUC}_{0-t}(\mathrm{~h} \mathrm{ng} / \mathrm{mL})$} \\
\hline Chinese & 15 & 3638.5 & 101.8 & $86.5-119.9$ \\
\hline Caucasian & 15 & 3574.0 & & \\
\hline \multicolumn{5}{|c|}{$\mathrm{AUC}_{0-\infty}(\mathrm{h} \mathrm{ng} / \mathrm{mL})$} \\
\hline Chinese & 15 & 3644.5 & 101.8 & $86.5-119.9$ \\
\hline Caucasian & 15 & 3580.0 & & \\
\hline \multicolumn{5}{|c|}{ Multiple doses $(50 \mathrm{mg})$} \\
\hline \multicolumn{5}{|c|}{$C_{\mathrm{max}, \mathrm{ss}}(\mathrm{ng} / \mathrm{mL})$} \\
\hline Chinese & 15 & 921.5 & 88.4 & $72.6-107.5$ \\
\hline Caucasian & $13^{\mathrm{a}}$ & 1042.9 & & \\
\hline \multicolumn{5}{|c|}{$\mathrm{AUC}_{0-\tau}(\mathrm{h} \mathrm{ng} / \mathrm{mL})$} \\
\hline Chinese & 15 & 3646.9 & 96.7 & $82.4-113.6$ \\
\hline Caucasian & $13^{\mathrm{a}}$ & 3769.8 & & \\
\hline \multicolumn{5}{|l|}{ BIA 9-1103 } \\
\hline \multicolumn{5}{|c|}{ Single dose $(25 \mathrm{mg})$} \\
\hline$C_{\max }(\mathrm{ng} / \mathrm{m}$ & & & & \\
\hline
\end{tabular}


Table 3 continued

\begin{tabular}{|c|c|c|c|c|}
\hline Parameter & $N$ & GM (LSM) & GMR (Chinese/Caucasian; \%) & $90 \%$ CI of GMR \\
\hline Chinese & 15 & 62.1 & 105.9 & $78.4-143.2$ \\
\hline Caucasian & 10 & 58.62 & & \\
\hline \multicolumn{5}{|c|}{$\mathrm{AUC}_{0-t}(\mathrm{~h} \mathrm{ng} / \mathrm{mL})$} \\
\hline Chinese & 15 & 2886.0 & 106.2 & $78.5-143.5$ \\
\hline Caucasian & 10 & 2718.6 & & \\
\hline \multicolumn{5}{|c|}{ Single dose $(50 \mathrm{mg})$} \\
\hline \multicolumn{5}{|c|}{$C_{\max }(\mathrm{ng} / \mathrm{mL})$} \\
\hline Chinese & 15 & 100.9 & 88.2 & $73.5-106.0$ \\
\hline Caucasian & 15 & 114.2 & & \\
\hline \multicolumn{5}{|c|}{$\mathrm{AUC}_{0-t}(\mathrm{~h} \mathrm{ng} / \mathrm{mL})$} \\
\hline Chinese & 15 & 4680.2 & 88.1 & $73.4-105.9$ \\
\hline Caucasian & 15 & 5310.7 & & \\
\hline \multicolumn{5}{|c|}{ Multiple doses $(50 \mathrm{mg})$} \\
\hline \multicolumn{5}{|c|}{$C_{\max , s \mathrm{~s}}(\mathrm{ng} / \mathrm{mL})$} \\
\hline Chinese & 15 & 403.7 & 90.6 & $74.8-109.7$ \\
\hline Caucasian & $13^{\mathrm{a}}$ & 445.8 & & \\
\hline \multicolumn{5}{|c|}{$\mathrm{AUC}_{0-\tau}(\mathrm{h} \mathrm{ng} / \mathrm{mL})$} \\
\hline Chinese & 15 & 8854.7 & 90.7 & $74.9-109.8$ \\
\hline Caucasian & $13^{\mathrm{a}}$ & 9766.1 & & \\
\hline
\end{tabular}

$A U C_{0-t}$ area under the plasma concentration-time curve from time 0 to the last sampling time with concentrations above the lower limit of quantitation, $A U C_{0-\infty}$ area under the plasma concentration-time curve from time 0 to infinity, $A U C_{0-\tau}$, area under the plasma concentration-time curve over the dosing interval, $C_{\max }$ maximum observed plasma concentration, $C_{\text {max }, s s} C_{\max }$ in steady state, $C I$ confidence interval, $L S M$ least-square mean, GM geometric mean, GMR geometric mean ratio, $O P C$ opicapone, $P K$ pharmacokinetics

${ }^{a}$ Two Caucasians discontinued treatment because of adverse events

total bilirubin level ( $25 \mathrm{mg}$ group, considered unlikely related to the use of OPC)]. Only four adverse drug reactions (ADRs) were reported by three subjects $(4.3 \%)$, which were presyncope (1.4\%), hyperhidrosis (1.4\%), belching (1.4\%), and bloating (1.4\%). No serious adverse events (SAEs) or death occurred. Two Caucasian subjects dropped out of the study because of AEs [presyncope (50 mg group, considered possibly related to the administration of OPC) and an increase in blood creatine phosphokinase level
(50 mg group, considered unlikely related to the use of OPC); Supplementary Table 1]. No clinically significant findings related to OPC were observed in laboratory tests, vital signs, physical examinations, and 12-lead ECGs. Overall, a lower incidence of AEs was observed in Chinese subjects compared with Caucasian subjects; however, the numbers were generally low. 

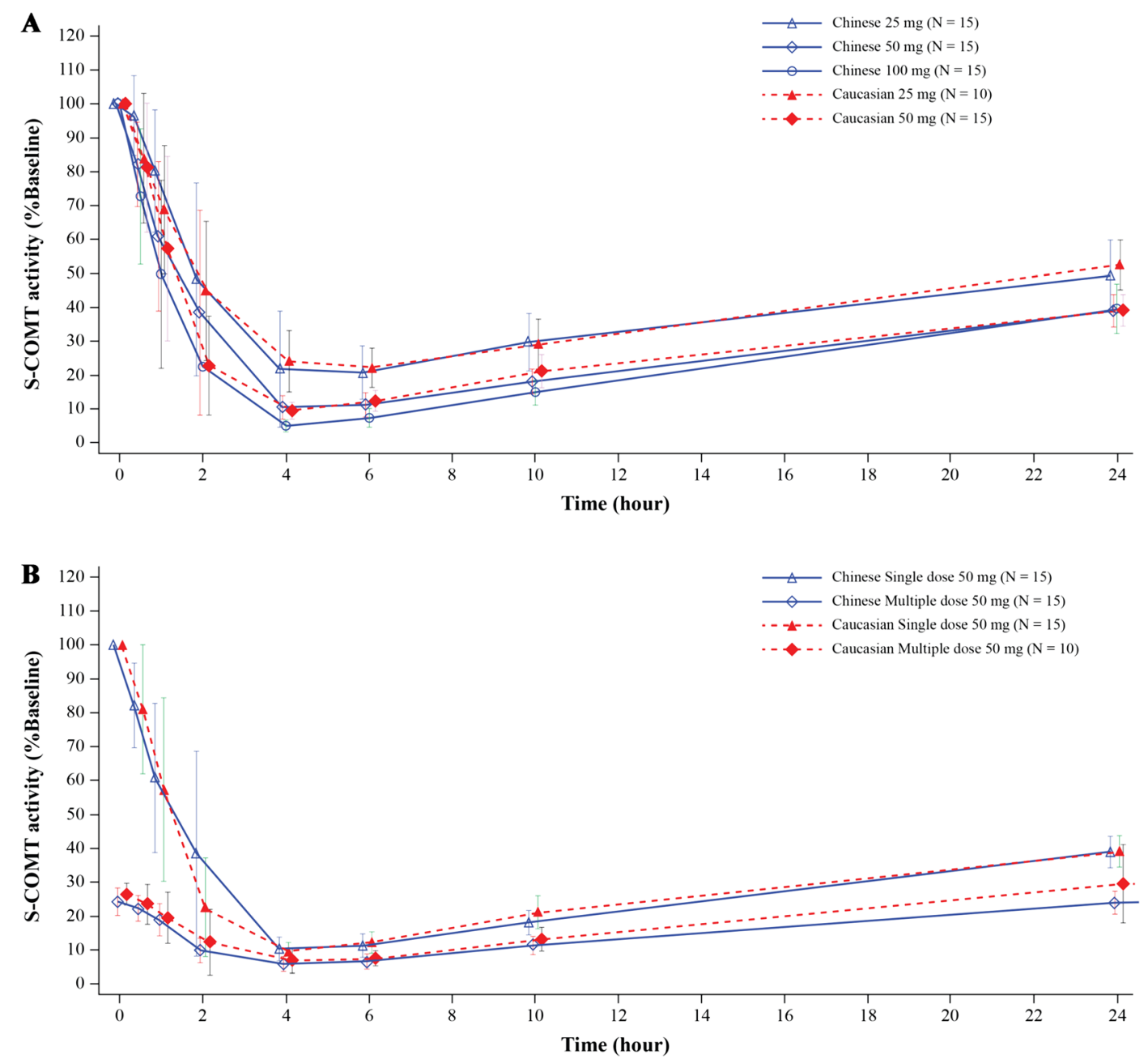

Fig. 4 Mean S-COMT activity-time profiles as a percentage of change concerning baseline after a single dose; $\mathbf{b}$ multiple doses. Error bars represent standard deviation. S-COMT, erythrocyte-soluble catechol-O-methyltransferase

\section{DISCUSSION}

The number of individuals diagnosed with Parkinson's disease is likely to grow substantially in the coming years. By 2030, the number of Chinese patients with Parkinson's disease is estimated to reach 4.94 million, accounting for half of the patients with Parkinson's disease worldwide [29]. OPC was recommended by Chinese guidelines for the treatment of Parkinson's disease (4th edition) as adjunctive treatment to levodopa/carbidopa [10]. However, it is still not available in China, despite the impending clinical need. Several studies have demonstrated the efficacy of OPC in Caucasian patients with Parkinson's disease [24, 25]. We, therefore, designed this study to evaluate whether OPC has comparable and bioequivalent PK and PD characteristics and effects between Chinese and Caucasians and provide further evidence for extrapolation of the foreign clinical data to China.

In the present study, the plasma exposure ( $C_{\max }$ and AUC) of OPC and its metabolite BIA 9-1103 increased with the increase in the dose $(25 \mathrm{mg}, 50 \mathrm{mg}$, and $100 \mathrm{mg})$. The $t_{\max }$ of OPC in Chinese and Caucasian subjects ranged from 2 to $3 \mathrm{~h}$, and the average $t_{1 / 2}$ ranged 
Table 4 Pharmacodynamic parameters of S-COMT after single- and multiple-dose administrations

\begin{tabular}{|c|c|c|c|c|c|c|}
\hline & $N$ & $\begin{array}{l}E_{0}[\mathrm{pmol} /(\mathrm{mgHb} / \\
\text { h)] }\end{array}$ & $\begin{array}{l}E_{\max }[\mathrm{pmol} /(\mathbf{m g H b} / \\
\text { h)] }\end{array}$ & $\begin{array}{l}\mathbf{T E}_{\max } \\
\text { (h) }\end{array}$ & $\begin{array}{l}\left(\left[E_{0}-E_{\max }\right] / E_{0}\right) \cdot 100 \\
(\%)\end{array}$ & $\begin{array}{l}\operatorname{AUEC}_{0-t} \\
(\% \cdot h)\end{array}$ \\
\hline \multicolumn{7}{|l|}{ Single dose } \\
\hline Chinese: $25 \mathrm{mg}$ & 15 & $15.8(29.11)$ & $2.7(51.8)$ & $4.5(20)$ & $82.7(7.9)$ & $1475.9(13.6)$ \\
\hline $50 \mathrm{mg}$ & 15 & $12.5(32)$ & $1.1(27.3)$ & $\begin{array}{l}4.7 \\
(19.1)\end{array}$ & $90.3(3.3)$ & $1742.5(6.5)$ \\
\hline $100 \mathrm{mg}$ & 15 & $13.0(35.4)$ & $0.5(40)$ & $\begin{array}{l}3.9 \\
(23.1)\end{array}$ & $95.2(1.9)$ & $1825.8(5.8)$ \\
\hline $\begin{array}{l}\text { Caucasian: } \\
25 \mathrm{mg}\end{array}$ & 10 & $15.7(40.8)$ & $3.3(54.5)$ & $\begin{array}{l}4.8 \\
(29.2)\end{array}$ & $79.7(6.0)$ & $1472.7(8.97)$ \\
\hline $50 \mathrm{mg}$ & 15 & $10.7(36.4)$ & $0.9(44)$ & $\begin{array}{l}3.7 \\
(32.4)\end{array}$ & $91.2(2.6)$ & $1738.3(4.6)$ \\
\hline \multicolumn{7}{|l|}{ Multiple doses } \\
\hline Chinese: $50 \mathrm{mg}$ & 15 & $12.5(32)$ & $0.6(33.3)$ & $\begin{array}{l}4.3 \\
(23.3)\end{array}$ & $94.3(2.1)$ & $8612.0(7.6)$ \\
\hline $\begin{array}{l}\text { Caucasian: } \\
50 \mathrm{mg}\end{array}$ & 10 & $10.7(36.4)$ & $0.6(66.7)$ & $\begin{array}{l}4.3 \\
(30.2)\end{array}$ & $94.4(2.1)$ & $7919.1(12.0)$ \\
\hline
\end{tabular}

$A U E C_{O-t}$ area under the inhibition of S-COMT activity-time curve from time 0 to the last sampling time with concentrations above the lower limit of quantitation, $E_{0} S$-COMT activity at baseline, $E_{\max }$ maximum $S$-COMT activity postdose administration; $\left(\left[E_{0}-E_{\max }\right] / E_{0}\right) \cdot 100$, the maximum percentage inhibition of S-COMT activity, $P D$ pharmacodynamic, $S$-COMT erythrocyte-soluble catechol- $O$-methyltransferase, $T E_{\max }$ time to reach $E_{\max }$

Data are presented as mean (coefficient of variation, \%). $\mathrm{AUEC}_{0-t}$ was $\mathrm{AUEC}_{0-24 \mathrm{~h}}$ for single dose and $\mathrm{AUEC}_{0-144 \mathrm{~h}}$ for multiple doses

between 0.7 and $1.3 \mathrm{~h}$ while the $t_{\max }$ of BIA 91103 ranged from 6 to $8 \mathrm{~h}$ and the average $t_{1 / 2}$ ranged from 52 to $58 \mathrm{~h}$. The PK characteristics of different dose groups were observed to be similar post-single-dose administration. Also, the metabolic characteristics of OPC with multiple administration for 10 days $(50 \mathrm{mg})$ were found to be similar to that of single administration and no accumulation was observed. After single and multiple administration, the overall PK parameters were found to be similar in Chinese and Caucasians.

There is a causal relationship between exposure to a medication and its therapeutic activity. Evaluation of PD and PK parameters helps to integrate quantitative information about the pharmacologic properties of a compound with its PK [30]. We observed an exposure-related increase in S-COMT inhibition. After a singledose administration of 25, 50, and $100 \mathrm{mg}$ OPC, the $C_{\max }$ and the maximum inhibition rates of S-COMT were 713.6, 1210.5, and $1898.0 \mathrm{ng} / \mathrm{mL}$ and $82.7 \%, 90.3 \%$, and $95.2 \%$, respectively in Chinese subjects, and after single-dose administration of 25 and $50 \mathrm{mg}$ OPC in Caucasians, the values were 556.3 and $1327.8 \mathrm{ng} / \mathrm{mL}$, and $79.7 \%$ and $91.2 \%$, respectively. Our results were consistent with a previous study (in which OPC was used in the range of $10-1200 \mathrm{mg}$ ) where a dose-dependent and long-lasting S-COMT inhibitory effect was reported, wherein the maximum and the 72-h post-dose S-COMT inhibition values were in the range of $34.5 \%$ $(10 \mathrm{mg})$ to $100 \%(1200 \mathrm{mg})$ and $5.9 \%(10 \mathrm{mg})$ to $54.6 \%$ (800 mg), respectively [18]. Similarly, in a multiple-dose escalating study, where OPC 5 to 
Table 5 Comparison of pharmacodynamic parameters of S-COMT after single- and multiple-dose administrations

\begin{tabular}{|c|c|c|c|c|}
\hline Chinese/Caucasian & $N$ & GM (LSM) & GMR (Chinese/Caucasian; \%) & $90 \%$ CI of GMR \\
\hline \multicolumn{5}{|l|}{ Single dose $(25 \mathrm{mg})$} \\
\hline \multicolumn{5}{|l|}{$E_{\max }$} \\
\hline Chinese & 15 & 70.1 & 97.1 & $92.3-102.1$ \\
\hline Caucasian & 10 & 72.2 & & \\
\hline \multicolumn{5}{|l|}{$\mathrm{AUEC}_{0-24 \mathrm{~h}}$} \\
\hline Chinese & 15 & 1349.7 & 97.6 & $92.9-102.6$ \\
\hline Caucasian & 10 & 1382.2 & & \\
\hline \multicolumn{5}{|l|}{ Single dose $(50 \mathrm{mg})$} \\
\hline \multicolumn{5}{|l|}{$E_{\max }$} \\
\hline Chinese & 15 & 87.3 & 98.5 & $95.1-102.1$ \\
\hline Caucasian & 15 & 88.6 & & \\
\hline \multicolumn{5}{|l|}{$\mathrm{AUEC}_{0-24 \mathrm{~h}}$} \\
\hline Chinese & 15 & 1686.5 & 100.2 & $97.3-103.2$ \\
\hline Caucasian & 15 & 1683.2 & & \\
\hline \multicolumn{5}{|c|}{ Multiple doses (50 mg) } \\
\hline \multicolumn{5}{|l|}{$E_{\max }$} \\
\hline Chinese & 15 & 99.9 & 99.8 & $96.9-102.8$ \\
\hline Caucasian & $13^{*}$ & 100.1 & & \\
\hline \multicolumn{5}{|l|}{$\mathrm{AUEC}_{0-144 \mathrm{~h}}$} \\
\hline Chinese & 15 & 8523.8 & 105.9 & $101.5-110.4$ \\
\hline Caucasian & $13^{*}$ & 8051.0 & & \\
\hline
\end{tabular}

$30 \mathrm{mg}$ was administrated in healthy subjects for 8 consecutive days, the PK and PD profiles were closely related to the administered dose as systemic exposure increased in approximately dose-proportional manner. Compared with a single dose, the inhibition of S-COMT lasted longer after the administration of multiple doses of OPC, with an inhibition ranging from $16.33 \%$ (5 mg) to $20.3 \%$ (30 mg) $144 \mathrm{~h}$ after the last dose [17]. Moreover, a dose-dependent increase in clinical outcomes was observed in phase 3 studies by Ferreira et al. and Lees et al.
$[24,25]$ demonstrating a relationship between exposure and therapeutic activity of OPC.

The PK and PD of drugs can be influenced by ethnicity which may further influence the dosage, efficacy, and safety of the drug in different regions. Hence, we further evaluated the effect of ethnicity on PK and PD profiles of OPC. From the results, the point estimates of GMRs (Chinese/Caucasian) were close to $100.0 \%$, and $90 \%$ CI of most of the PK and PD parameters of OPC, except the $90 \% \mathrm{CI}$ of $C_{\max }$ in 25 and $50 \mathrm{mg}$, fell within the range of $80 \%$ to $125 \%$, 
indicating no significant differences in PK and PD profiles between Chinese and Caucasian subjects. So, we can conclude that no sensitivity to ethnicity exists as indicated by similar PK and PD characteristics. The large width or large variability reflected in $90 \%$ CI of the PK and PD parameters may be due to the parallel design (instead of a cross-over) inducing between-subject variability in the comparison, and also due to the low and imbalanced number of subjects between Chinese and Caucasian 25-mg dose groups. These findings were consistent with a previous multiple ascending dose study $(N=38)$. After administration of OPC (5-, 25-, or $50 \mathrm{mg}$ capsules) once daily for 10 days, comparable PK and PD profiles were reported between the healthy Japanese and matched white subjects [20]. The PK profiles of the present study and the Japanese study were comparable. The $C_{\max }$ and $\mathrm{AUC}_{0-t}$ obtained in the present study among Caucasians with $25 \mathrm{mg}$ $(556.3 \mathrm{ng} / \mathrm{mL}$ and $1622.8 \mathrm{~h} \mathrm{ng} / \mathrm{mL}$, respectively) and $50 \mathrm{mg} \quad(1327.8 \mathrm{ng} / \mathrm{mL}$ and $3802.1 \mathrm{~h} \mathrm{ng} / \mathrm{mL}$, respectively) were slightly lower than the values in the Japanese study ( $25 \mathrm{mg}$ : $794 \mathrm{ng} / \mathrm{mL}$ and $2013 \mathrm{~h} \mathrm{ng} / \mathrm{mL}$, respectively; $50 \mathrm{mg}: 1540 \mathrm{ng} / \mathrm{mL}$ and $3727 \mathrm{~h} \mathrm{ng} / \mathrm{mL}$, respectively). The $C_{\max }$ and $\mathrm{AUC}_{0-t}$ reported in Chinese volunteers in the present study at $25 \mathrm{mg} \quad(713.6 \mathrm{ng} / \mathrm{mL}$ and $1848.9 \mathrm{~h} \mathrm{ng} / \mathrm{mL}$, respectively) were similar to the values reported in Japanese patients (797 ng/mL and $1886 \mathrm{~h} \mathrm{ng/}$ $\mathrm{mL}$, respectively) but slightly higher values were reported with the 50-mg dose in Japanese patients $(1736 \mathrm{ng} / \mathrm{mL}$ and $4438 \mathrm{~h} \mathrm{ng} / \mathrm{mL}$, respectively).

Our results revealed a lower incidence of AEs in Chinese compared with Caucasian subjects. ADRs reported in our study included presyncope, hyperhidrosis, belching, and bloating. No new risks or safety concerns were identified in this study.

Our study was the first clinical study to evaluate the PK, PD, and safety parameters of OPC in the Chinese population. Our results showed that OPC is not sensitive to ethnicity; hence, this study could be a bridging study and, to a certain extent, supported the extrapolation of clinical data from Caucasians to Chinese. OPC may serve as a new promising therapeutic option for Parkinson's disease in China. There are some limitations of our study. First, the number of Caucasian subjects in the 25-mg group was less than planned. Thus, the assessment of ethnic differences may not be adequate. Second, as a short-term phase 1 study, the safety profile of OPC could not be fully captured, and the long-term safety of OPC was left uninvestigated. In addition, a high screening failure rate was observed because of the COVID-19 pandemic. Safety monitoring and assessment of OPC in a larger population is warranted, which may provide further insights.

\section{CONCLUSIONS}

Ethnicity had no significant impacts on PK and PD profiles in Chinese and Caucasian subjects after taking single or multiple doses of OPC. OPC was safe and well tolerated in healthy Chinese subjects.

\section{ACKNOWLEDGEMENTS}

We thank the participants of the study.

Funding. This study was sponsored by Wanbang Biopharmaceuticals Co., Ltd. The Journal's Rapid Service Fee was funded by Shanghai Fosun Pharmaceutical Development, Co., Ltd.

Medical Writing Assistance. The authors acknowledge Dr. Sunita Rana and Dr. Satya Jakki (Indegene Pvt. Ltd., Bengaluru, India) for providing medical writing assistance in the development of this manuscript (funded by Shanghai Fosun Pharmaceutical Development, Co., Ltd.).

Authorship. All named authors meet the International Committee of Medical Journal Editors (ICMJE) criteria for authorship for this article, take responsibility for the integrity of the work as a whole, and have given their approval for this version to be published. 
Author Contributions. JL, YZ, A-MH and KL equally contributed to the study's conception, and design. Material preparation, data collection, and analysis were performed by DC, JS, YL, YT, WX, XL, WQ and XY. YZ, A-MH, and KL supervised and commented on the draft of the manuscript. All authors read and approved the final manuscript.

Disclosures. Jie Song, Yan Tan, Jun Lu, and Ai-Min Hui are employees of Shanghai Fosun Pharmaceutical Development, Co., Ltd., Shanghai, China. Xiaojuan Yuan and Yongchun Zhou are employees of Wanbang Biopharmaceuticals Co., Ltd. Duanduan Cong, Yue Liu, Wei Xue, Xiaohui Liu, Wenyuan Qi, and Kexin Li have nothing to disclose.

Compliance with Ethics Guidelines. The study protocol was reviewed and approved by the ethics committee of Beijing Hospital (Beijing, China, Approval number 2019BJYYEC100-01). Written informed consent was obtained from each subject before participating in the study. All authors confirm that our study was performed following the Good Clinical Practice (GCP) as well as the Helsinki Declaration of 1964 and its later amendments.

Data Availability. The datasets generated during and/or analyzed during the current study are available from the corresponding author on reasonable request.

Open Access. This article is licensed under a Creative Commons Attribution-NonCommercial 4.0 International License, which permits any non-commercial use, sharing, adaptation, distribution and reproduction in any medium or format, as long as you give appropriate credit to the original author(s) and the source, provide a link to the Creative Commons licence, and indicate if changes were made. The images or other third party material in this article are included in the article's Creative Commons licence, unless indicated otherwise in a credit line to the material. If material is not included in the article's Creative Commons licence and your intended use is not permitted by statutory regulation or exceeds the permitted use, you will need to obtain permission directly from the copyright holder. To view a copy of this licence, visit http://creativecommons.org/licenses/by$\mathrm{nc} / 4.0 /$.

\section{REFERENCES}

1. Schapira AHV, Emre M, Jenner P, Poewe W. Levodopa in the treatment of Parkinson's disease. Eur J Neurol. 2009;16:982-9.

2. Agid Y, Ahlskog E, Albanese A, et al. Levodopa in the treatment of Parkinson's disease: a consensus meeting. Mov Disord. 1999;14:911-3.

3. Olanow CW, Agid Y, Mizuno Y, et al. Levodopa in the treatment of Parkinson's disease: current controversies. Mov Disord. 2004;19:997-1005.

4. Gershanik OS. Improving L-dopa therapy: the development of enzyme inhibitors. Mov Disord. 2015;30:103-13.

5. Baas H, Beiske AG, Ghika J, et al. Catechol-Omethyltransferase inhibition with tolcapone reduces the "wearing off" phenomenon and levodopa requirements in fluctuating parkinsonian patients. Neurology. 1998;50:S46-53.

6. Olanow CW, Stocchi F. COMT inhibitors in Parkinson's disease: can they prevent and/or reverse levodopa-induced motor complications? Neurology. 2004;62:S72-81.

7. Bonifácio MJ, Palma PN, Almeida L, Soares-da-Silva P. Catechol-O-methyltransferase and its inhibitors in Parkinson's disease. CNS Drug Rev. 2007;13: 352-79.

8. Grimes D, Fitzpatrick M, Gordon J, et al. Canadian guideline for Parkinson disease. CMAJ. 2019;191: E989-1004.

9. Fox SH, Katzenschlager R, Lim S-Y, et al. International Parkinson and Movement Disorder Society evidence-based medicine review: update on treatments for the motor symptoms of Parkinson's disease. Mov Disord. 2018;33:1248-66.

10. Chinese Society of Parkinson's Disease and Movement Disorders. Chinese guidelines for the treatment of Parkinson's disease (fourth edition). Chin J Neurol. 2020;53:973-86.

11. Deane KHO, Spieker S, Clarke CE. Catechol-Omethyltransferase inhibitors for levodopa-induced complications in Parkinson's disease. Cochrane Database Syst Rev. 2004;(4):CD004554. 
12. Brooks DJ. Safety and tolerability of COMT inhibitors. Neurology. 2004;62:S39-46.

13. Dingemanse J. Issues important for rational COMT inhibition. Neurology. 2000;55:S24-27 (discussion S28-32).

14. Kiss LE, Ferreira HS, Torrão L, et al. Discovery of a long-acting, peripherally selective inhibitor of catechol-O-methyltransferase. J Med Chem. 2010;53: 3396-411.

15. Gonçalves D, Alves G, Fortuna A, Soares-da-Silva P, Falcão A. Pharmacokinetics of opicapone, a thirdgeneration COMT inhibitor, after single and multiple oral administration: a comparative study in the rat. Toxicol Appl Pharmacol. 2017;323:9-15.

16. Palma PN, Bonifácio MJ, Loureiro AI, Soares-daSilva P. Computation of the binding affinities of catechol-O-methyltransferase inhibitors: multisubstate relative free energy calculations. J Comput Chem. 2012;33:970-86.

17. Rocha JF, Almeida L, Falcão A, et al. Opicapone: a short lived and very long acting novel catechol-Omethyltransferase inhibitor following multiple dose administration in healthy subjects. Br J Clin Pharmacol. 2013;76:763-75.

18. Almeida L, Rocha JF, Falcão A, et al. Pharmacokinetics, pharmacodynamics and tolerability of opicapone, a novel catechol-O-methyltransferase inhibitor, in healthy subjects: prediction of slow enzyme-inhibitor complex dissociation of a shortliving and very long-acting inhibitor. Clin Pharmacokinet. 2013;52:139-51.

19. Myöhänen TT, Schendzielorz N, Männistö PT. Distribution of catechol-O-methyltransferase (COMT) proteins and enzymatic activities in wildtype and soluble COMT deficient mice. J Neurochem. 2010;113:1632-43.

20. Falcão A, Rocha JF, Santos A, Nunes T, Soares-daSilva P. Opicapone pharmacokinetics and pharmacodynamics comparison between healthy Japanese and matched white subjects. Clin Pharmacol Drug Dev. 2016;5:150-61.

21. Xue W, Tan Y, Liu Y, et al. Pharmacokinetics of opicapone and its metabolites in healthy white and
Chinese subjects. Clin Pharmacol Drug Dev. 2021;10:1316-24.

22. US Food and Drug Administration. International Conference on Harmonisation; guidance on ethnic factors in the acceptability of foreign clinical data; availability-FDA. Notice. Fed Regist 1998;63: 31790-6.

23. Center for Drug Evaluation. Technical guidelines for clinical pharmacokinetic research of chemical drugs. 2005. https://www.cde.org.cn/zdyz/ domesticinfopage?zdyzIdCODE = 4247ffceca57f2b47aa0f67a3fdc7c43. Accessed 5 Dec 2021

24. Lees AJ, Ferreira J, Rascol O, et al. Opicapone as adjunct to levodopa therapy in patients with Parkinson disease and motor fluctuations: a randomized clinical trial. JAMA Neurol. 2017;74: 197-206.

25. Ferreira JJ, Lees A, Rocha J-F, et al. Opicapone as an adjunct to levodopa in patients with Parkinson's disease and end-of-dose motor fluctuations: a randomised, double-blind, controlled trial. Lancet Neurol. 2016;15:154-65.

26. ONGENTYS (opicapone) capsules, for oral use Initial U.S. Approval: 2020. https://www.accessdata. fda.gov/drugsatfda_docs/label/2020/ 212489s000lbl.pdf. Accessed 5 Dec 2021

27. Vieira-Coelho MA, Soares-da-Silva P. Ontogenic aspects of liver and kidney catechol-O-methyltransferase sensitivity to tolcapone. Br J Pharmacol. 1996;117:516-20.

28. Vieira-Coelho MA, Soares-da-Silva P. Effects of tolcapone upon soluble and membrane-bound brain and liver catechol-O-methyltransferase. Brain Res. 1999;821:69-78.

29. Dorsey ER, Constantinescu R, Thompson JP, et al. Projected number of people with Parkinson disease in the most populous nations, 2005 through 2030. Neurology. 2007;68:384-6.

30. Tuntland T, Ethell B, Kosaka T, et al. Implementation of pharmacokinetic and pharmacodynamic strategies in early research phases of drug discovery and development at Novartis Institute of Biomedical Research. Front Pharmacol. 2014;5:174. 